\title{
Potential Endophytic Bacteria for Increasing Paddy Var Rojolele Productivity
}

\author{
Desriani $^{1 \# \text {, Dwi Endah Kusumawati }}{ }^{2}$, Akhmad Rivai ${ }^{1}$, Neneng Hasanah ${ }^{1}$, \\ Wiwit Amrinola ${ }^{1}$, Lita Triratna ${ }^{1}$ and Ade Sukma ${ }^{1}$ \\ ${ }^{I}$ Research Centre for Biotechnology, LIPI. Jl. Raya Bogor Km 46, Kec. Cibinong, \\ Kab. Bogor, 16911. Indonesia. Telp: +62-21-8754587. \\ E-mail:"\#gerodes@yahoo.com \\ ${ }^{2}$ Department of Biochemistry, Bogor Agriculture University, Indonesia.
}

\begin{abstract}
Paddy var Rojoleleis asuperior paddy come from Klaten that released by Department of Agriculture in 2003. Its superior properties are resistant to pests leaf hoppers, fluffier, and fragrant. To increase the productivity of paddy that are of ten used by farmers is to use chemical-based fertilizers. The use of these chemicals will effect to adisruption of ecosystem balancing, reduction the amount of soil microflora which essential forplants. Endophytic bacteria are symbiotic microorganisms living within plant tissues, and does not cause negative effects on the host plant. Endophytic bacteria have a capability increasing crop productivity by producing growth hormone, contributes to plant health, and as bio-control agents. Some endophytic bacteria which contribute to plant growth are: Pseudomonas sp., Enterobacter sp., Staphylococcus sp., Azotobacter sp., And Azospirilum sp., Whereas endophytic bacteria that contribute to the health and plant protection several of them are: Pseudomonas sp., Serratia sp. ,Clavibacter sp., and Bacillus sp. This study was conducted to investigate potential of endophytic bacteria to increase Paddy var Rojolele productivity based on its ability to produce extracellular enzymes and resistance to multiple types of antibiotics. The method were endophytic bacteria isolation from three Paddy varRojolele plants, extracellular enzymes detection and antibiotic resistance testing to chloramfinekol, ampicillin and kanamycin. As the result, 43isolateswere isolated from Paddy var Rojolele. Four isolatesamong them havethe ability to produce extra cellular enzym esandresistant toampicillin, kanamycin, and chloramfinekol. Extra cellular enzyme production capability and resistance to antibiotics makes endophytic bacteria are potentialto improveplant health and also asbio-control agentwhich then willaffect to the productivity of rice. To further ensure its potential to plant, more research is needed.
\end{abstract}

Keywords - Paddy var Rojolele, Endophytic Bacteria, extracellular enzymes, antibiotics resistance, productivity.

\section{INTRODUCTION}

Rice is an important plant for diet more than $50 \%$ of the world population (Hossain and Fischer 1995). Paddy varRojolele is a superior paddy that resistance to pests leafhoppers, fluffier, and fragrant. As the result of growth population,we need to improve rice productivity. However, the yield was decreased and rice disease can be a factors that reducerice productivity (Manuwoto dan Indriyani 1994).

The common approach for control rice disease is using chemical fertilizer. Chemical fertilizer such as pesticides, herbicides, and insecticides has a negative effect such as decrease the soil microflora, induce resistance of pathogens, and the residue may affect to humans and animal's health. The alternative to subtitute chemical fertilizer is use an endophytic bacteria.

Endophytic bacteria is a bacteria that living at internal tissues of the plant and doesn't show a negative effect on their host (Mano and Morisaki 2008). Its can be enter to plant tissue via root zone and aerial portions (Kobayasi and Palumbo 2000), germinating radicles (Gagne et al. 1987), or through foliar damage (Leben et al. 1968) then colonized at spesific tissue or spread throughout the plant. Generally, endophytic bacteria are abundant in roots and decrease in stem and leaves (Lamb et al. 1996), but sometimes its larger in stem than in the root (Koomnok et al. 2007).

Endophytic bacteria can enhance plant growth by producing plant growth promoting hormones (IAA, cytokinin, and giberellin), fix nitrogen or dissove phosporus (Hardoim et al. 2008). Moreover, endophytes can also promote plant health, and have ability as a biocontrol agent (Ryan et al. 2007). The capability to colonize internal tissue make endophytic bacteria can against pathogens by mechanism of competitive site and nutrient or produce antagonistic subtances (Pal et al. 2012). The penetrate of endophytic bacteria to internal tissues of the plant is 
connected by their capability to produce cellulase (Benhamou et al. 1996).

The aim of this paper was to investigate potential of endophytic bacteria to increase Paddy var Rojolele productivity based on its ability to produce extracellular enzyme (cellulase), and resistance to three different antibiotics at the concentration tested.

\section{MATERIAL AND METHOD}

\section{A. Isolation of Endophytic Bacteria}

Fresh root, stem segments (middle and stip), and leaves were cut from rice plant (var. Rojolele) and washed under running tap water. The samples were surface sterilized by immersion in $96 \%$ ethanol (1 minute), 5.25\% sodium hiperchlorite (5 minute), and again with $96 \%$ ethanol for 30 sec (3 times). The samples were cut into small pieces and plated aseptically on prepared NA with nistatin added. The plates were incubated in dark at room temperature.

\section{B. Cellulase Qualitative Test}

The test isolates were spot-inoculated on the CMC agar plates and incubated for 3 days at room temperature. The composition of CMC agar media are: CMC, yeast extract, glucose, MgSO4.7H2O, KNO3, K2HPO4, FeSO4.7H2O, and $\mathrm{CaCl} 2$. The plates were flooded with $0.1 \%$ of congo red and $2 \%$ of $\mathrm{NaCl}$. Clear zone around isolate's colony indicate that the isolate produce cellulase.

\section{Antibiotic resistance Test (Modification of Zinnielet al. 2002)}

The test isolates were spot-inoculated on LB agar plates that containing antibiotics (kanamycin $10 \mu \mathrm{g} / \mathrm{mL}$; chloramphenicol $50 \mu \mathrm{g} / \mathrm{m}$; , ampicillin $50 \mu \mathrm{g} / \mathrm{mL}$ ) and incubated for 2 days at room temperature. Bacteria were resistance to antibiotic will growth at the concentration tested.

\section{RESULT AND DISCUSSION}

\section{A. Isolation Of Endophytic Bacteria.}

A total of 43 endophytic bacteria were isolated from Paddy var. Rojolele, comprises of 17 isolates from rhizoma (BO), 13 isolates from middle stem (BT), 11 isolates from tip stem (BU), and 2 isolates from leaves (Figure1). As the result endophytic bacteria more abundant in stem (30 isolates) than in root or leaves. This may be because product of photosynthesis being transported from leaves to all part of the plant through the phloem (Koomnoket al. 2007) so it can be a nutrition sources for endophytic bacteria.

\section{B. Cellulase Qualitative Test}

To determine which of isolate had the ability to produce an extracellular enzyme expecially cellulase, we carried out studies with spot-inoculated the isolates in CMC plate agar. After three days incubation, around 21 isolates showed a clear zone around colony after congo red treatment that indication of cellulose degradation by cellulase (Figure 1).

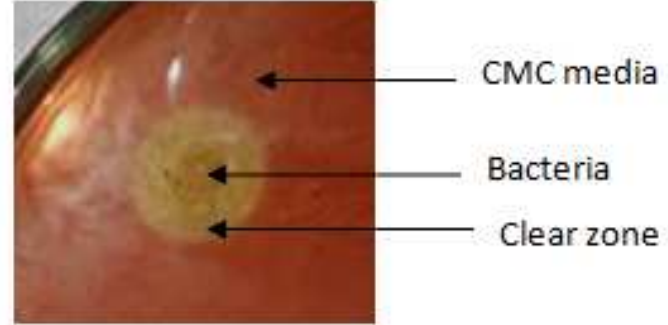

Fig. 1.Generated clear zone around colony after congo red treatment.

\section{Antibiotic Resistance Profile}

Antibiotic resistance of endophytic bacteria isolates was studied against three different antibiotics: kanamycin, chloramphenicol, and ampicillin. The result shows that 10 isolates from rhizoma, 3 isolates from middle stem, and 2 isolates from tip stem are resistance with three antibiotics at concentration test. The similar ability of antibiotic resistance among the isolates may be bacause horizontal transferred of antibiotic resistance genes from enviromental isolates to other microorganism include endophytic bacteria (Arunachalam and Gayathri 2010).

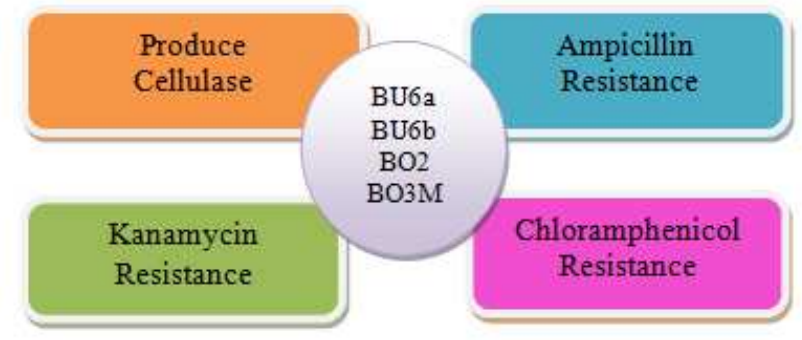

Fig. 2. Four bacteria isolates which shown produce cellulase and resistant to three kind of antibiotik.

Among 43 isoltaes, four isolates have the ability to produce extra cellular enzymes and resistant to ampicillin, kanamycin, and chloramfinekol (Figure 2). Extra cellular enzyme production capability and resistance to anti biotics makes endophytic bacteria are potential to improve plant health and also asbio-control agent which then will affect to the productivity of rice. To further ensure its potential to plant, more research is needed.

\section{CONCLUSIONS}

There are four isolates that have ability to produce cellulase and resistance with three different antibiotics at concentration test. This four bacteria isolates might be potential to improve plant health and also as biocontrol agent that will affect to the rice productivity.

\section{REFERENCES}

[1] Arunachalam C, Gayathri P. 2010. Studies on bioprespecting of endophytic bacteria from the medicinal plant of Andrographis paniculata for their antimicrobial activity and antibiotic susceptibility. Int J Curr Pharm Res 2: 63-68.

[2] Benhamou N, Belanger RR, Paulitz TC. 1996. Induction of diferential host responses by Pseudomonas fluorescens in Ri T-DNAtransformed pea roots after challenge with Fusarium oxysporum f. sp. Pisi dan Pythium ultimum. Phytopathol 86: 1174-1185. 
[3] Gagne S, Richard C, Rousseau H, Antoun H. 1987. Xylem-residing bacteria in alfalfa roots. Can. J. Microbiol. 33:996-1000.

[4] Hardoim PR, van Overbeek LS, van Elsas JD. 2008. Properties of bacterial endophytes and their proposed role in plant growth. Trends Microbiol16:463-471.

[5] Hossain, M. and Fischer, K. S., Rice research for food securityand sustainable agricultural in Asia: achievements and futurechallenges. GeoJournal, 1995, 35, 286-289.

[6] Kobayashi DY, Palumbo JD. 2000. Bacterial endophytes and their effects on plants and uses in agriculture: 199-233. In C. W. Bacon and J. F. White (ed.), Microbial endophytes. New York: Marcel Dekker, Inc.

[7] Koomnok C, Teaumroong N, Rerkasem B,Lumyong S. 2007. Diazotrophendophytic bacteria in cultivated and wild rice in Thailand.Science Asia 33: 429-435.
[8] Lamb TG, Tonkyn DW, Kluepfel DA. 1996. Movement ofPseudomonasaureofaciens from the rhizosphere to aerial plant tissue. Can. J.Microbiol. 42:1112-1120.

[9] Leben C, Daft GC, Schmitthenner AF. 1968. Bacterial blight ofsoybeans: population levels of Pseudomonas glycinea in relation to symptomdevelopment. Phytopathology58:1143-1146.

[10] Mano H dan H Morisaki. 2008. Minireview: Endophytic bacteria in the rice plant. Microbes and Environments23: 109-117.

[11] Manuwoto S, Indriyani N. 1994. Perkembangan, kelangsungan hidup dan reproduksi wereng cokelat Nilavarpata lugens (StaI) (Homoptera: Delphacidae) pada empat varietas padi. Buletin HPT 7: 61-67.

[12] Pal A, Chattopadhyay A, Paul AK. 2012. Diversity and Antimicrobial Spectrum of Endophytic Bacteria Isolated from Peaderi foetida L. Int J Curr Pharm Res 4 (3): 123-127.

[13] Ryan RP, Germaine K, Franks A, Ryan DJ, Dowling DN. 2008. Minireview: Bacterial endophytes: recent development and application. FEMS Microbiol Lett 278: 1-9. 